\title{
Why is income inequality increasing in the developed world?*
}

\author{
$\operatorname{Max}_{\text {Roser }^{\dagger} \quad \text { Jesus Crespo Cuaresma }}{ }^{\ddagger}$
}

\begin{abstract}
We address empirically the factors affecting the dynamics of income inequality among industrialized economies. Using a panel for 32 developed countries spanning the last four decades, our results indicate that the predictions of the Stolper-Samuelson theorem concerning the effects of international trade on income inequality find support in the data if we concentrate on imports from developing countries as a trade measure, as theory would imply. We find that democratization, the interaction of technology and education and changes in the relative power of labour unions affect inequality dynamics robustly.
\end{abstract}

Keywords: Inequality, international trade, FDI, globalization, institutions

JEL codes: D63, I24, F10

*The authors would like to thank Tony Atkinson, Conchita D'Ambrosio (the editor) and two anonymous referees for helpful comments to earlier versions of this paper. Max Roser would like to thank the Institute for New Economic Thinking at Oxford for their hospitality during the preparation of this study and the Office of the Vice Rector for Research at the University of Innsbruck for financial support.

$\dagger$ Institute for New Economic Thinking, Oxford Martin School, University of Oxford. Address: Eagle House, Walton Well Road, Oxford. Email: max.roser@economics.ox.ac.uk

${ }_{\ddagger}^{\ddagger}$ Department of Economics, Vienna University of Economics and Business (WU); Wittgenstein Centre for Demography and Global Human Capital (WIC); World Population Program, International Institute of Applied Systems Analysis (IIASA) and Austrian Institute of Economic Research (WIFO). Address: Welthandelsplatz 1, 1020 Vienna (Austria). Email: jcrespo@wu.ac.at. 


\section{Introduction}

In this paper we analyse empirically the factors behind the dynamics of inequality in industrialized countries during the last four decades. Although we focus on the interplay between globalization and income inequality, a subject where theory has provided clear-cut predictions but empirical work often delivers contradictory results, we aim at a more comprehensive assessment of the drivers of inequality in advanced economies than those offered by the empirical studies hitherto.

The available empirical literature tends to concentrate individually on particular theories and mechanisms, while abstracting from assessing simultaneously other arguably important driving forces. Given the fact that the theoretical literature on the determinants of inequality offers a manifold of explanatory frameworks which are not necessarily mutually exclusive, most of the contributions in the literature lack important controls and thus tend to offer fragmentary evidence. The strong differences in the results of the existing empirical studies can be thus traced back not only to differences in the coverage of countries and time periods and in the econometric methods used, but also to the partial nature of many of the models used to assess the determinants of inequality.

Our analysis improves on existing studies in several ways. Firstly, we use the largest sample of data available for industrialized economies, which spans data for 32 countries over four decades and employ modern econometric methods based on dynamic panel data models which explicitly account for potential endogeneity problems (see Blundell and Bond, 1998). These statistical issues have not been taken into account by many of the existing studies on the subject, which may have led to sizeable biases in parameter estimates. On the other hand, we concentrate on models which comprise different explanatory factors for inequality dynamics, instead of including explanatory variables which exclusively relate to single theoretical mechanisms. In particular, we include explanatory factors related to theories of technological change, international trade and political conditions and institutions as determinants of income inequality.

In our analysis we put particular effort in assessing the role played by international trade in shaping inequality dynamics. In order to mirror the theoretical setting implied by the Heckscher-Ohlin model - and especially by its corollary, the Stolper-Samuelson theorem - we assess explicitly the effect of different trade flows on inequality measures instead of concentrating on aggregate trade openness measures. In particular, we construct measures of trade flows between developing countries and developed economies, thus remaining closer to the theoretical framework of the Heckscher-Ohlin model, which focuses on countries with different factor endowments. Our results robustly show that, in line with the predictions of the Stolper-Samuelson theorem and in contrast to many existing empirical studies, imports from low-income countries do increase inequality in industrialized economies. In addition, the size of the government, political regime changes, unionization and the interplay between education expansion and technological change appear as further important determinants of within-country variation in the Gini index.

The paper is organized as follows. Section 2 presents a brief survey of the existing empirical studies dealing with the determinants of income inequality. Section 3 shows descriptive evidence on the dynamics of inequality in our sample of 32 industrialized economies. Section 4 presents the theoretical explanations provided by the literature on the determinants of inequality and 
describes the variables used to approximate the determinants implied by such theories. Section 5 sets up the econometric model and presents the data, while the results of the estimation of our econometric models are presented in section 6. Section 7 concludes.

\section{The Determinants of Income Inequality: A Bird's Eye Review of the Recent Literature}

Unveiling the determinants of inequality empirically has been the focus of a large number of studies in the last decades. Several recent publications empirically study the role played by different socioeconomic variables as determinants of inequality both within and between countries, concentrating often on single explanatory mechanisms.

Some of these studies explicitly focus on the impact of international trade and globalization on income inequality. Reuveny and Li (2003) assesses the effects of trade and democracy on inequality. Using data for a broad panel of countries, they find that both trade and democracy decrease income inequality. Dreher and Gaston (2008) assess whether globalization increased inequality using an index which merges several measures related to various aspects of globalization. Mahler (2004), on the other hand, examines the causes of income inequality and finds only weak evidence concerning the effect of forces related to international integration. On the other hand, variables that relate to domestic influences - the partisan balance of national cabinets, electoral turnout, union density, and the centralization of wage-setting institutions - are found not to have a strong effect on inequality. Jaumotte et al. (2008) investigate the rise of income inequality in 20 industrialized countries and 31 developing countries and also focus on the effects of globalization. They find that trade globalization has no effect on inequality measures but financial globalization does increase inequality. Increases in foreign direct investment (FDI) are thus found to be associated with rising inequality.

Another group of studies focuses on the distributional effects of political and institutional factors. Calderón et al. (2005) use a large panel of 121 countries spanning the three decades between 1970 and 2000 and highlight the relevance of labour market regulations. Baccaro (2011) finds that neither trade unionism nor collective bargaining tend to be statistically associated with lower income equality. The differences in the nature of the political interference of states in the market and its effect on inequality is at the heart of the analysis carried out by Rueda and Pontusson (2000), in the spirit of the so-called Varieties of Capitalism paradigm (see Hall and Soskice, 2001, as the core text of this school). The results of Rueda and Pontusson (2000) concerning the determinants of the ratio of the ninth to the first income deciles for 16 OECD countries indicate that union density is the most important factor behind inequality dynamics and that "[its] effects are consistently egalitarian and they are greater than those of any other independent variable" (Rueda and Pontusson, 2000, p. 352). Pontusson et al. (2002) focus on the role of partisanship and labour market institutions as determinants of inequality in different parts of the income distribution. They find that unionization, centralization of wage bargaining and public-sector employment primarily affect the distribution of wages by affecting the relative position of unskilled workers, while the upper half of the distribution is primarily influenced by the partisanship of the government. 
Oliver (2008) studies the dynamics of wage inequality in a panel of 14 OECD member states between 1980 and 2002 and finds that industry-wide wage scales are systematically related to within-country inequality changes. Beramendi and Cusack (2008) use a panel of 13 OECD countries and focus on the persistence in inequality measures. They explain these long-term differences as a consequence of the work of unions and political actors. Koeniger et al. (2007) study the causes of income inequality in 11 OECD member states concentrating on labour market variables and conclude that labor market institutions can account for a large part of the change of income inequality between countries.

This compact review of some of the most relevant empirical studies in the recent literature reveals a multitude of partly contradictory results based on different samples, methods and (fragmentary) theoretical frameworks. We aim at providing a more comprehensive view of the driving factors of inequality than the studies hitherto, basing our analysis on adequate methods to assess the potential endogeneity problems of the econometric specification and combining information of the different frameworks available in theory.

\section{Income Inequality in the Developed World: Data and Dynamics}

Before specifying econometric models, we start by exploring the overall long-run dynamics of inequality in advanced economies. Data on economic inequality is notoriously problematic. One of the major pitfalls of existing cross-country datasets is the combination of sources which are based on different definitions of income inequality. Data may differ in terms of the included sources of income (capital versus labour income) or of recipients (households versus workers). Datasets are thus difficult to compare and data that combine different sources are often severely criticized.

- Include Figure 1 here -

The dataset by Deininger and Squire (1996) combined data for many countries and for some time was the most widely used dataset and a number of the studies surveyed in the previous section are based on this source. The downside of the dataset by Deininger and Squire (1996) is that Gini indices differ in terms of income definitions (e.g. gross or net) and reference units (e.g., households or persons). After the critique from Atkinson and Brandolini (2001) other datasets (or corrections of the Deininger-Squire data) tend to be preferred in empirical studies comprising information for several countries.

\section{- Include Figure 2 here -}

Variability of the inequality measure in the time dimension appears particularly important to disentangle the effect of its determinants and to assess the potential endogeneity problems in the relationships under scrutiny. In this respect, the Estimated Household Income Inequality (EHII) dataset (Galbraith and Kum, 2005), which corrects the Deininger-Squire data by utilizing the data on income dispersion sourced from the United Nations Industrial Development 
Organization (UNIDO), appears as the natural choice for our purpose, taking into account the deficiencies of other existing datasets. The EHII dataset interpolates missing data gaps in the original sources using the data sourced from UNIDO. This is achieved using regressions of income inequality (Gini) indices from the Deininger-Squire dataset on the UNIDO variable and other covariates, including controls for the type of data source. ${ }^{1}$ Thereby, a dataset is assembled for (partly estimated) household gross income Gini indices in a comprehensive and consistent manner. The dataset is a large unbalanced panel for 154 countries from 1963 through 2002 with nearly 3,200 country-year observations.

In spite of its broad coverage and homogeneous approach to interpolating missing data, some limitations of the EHII data should be noted. To the extent that the figures in the EHII data are partly estimated, they may be subject to biases. By concentrating on information on manufacturing wages in order to achieve a consistent interpolation exercise, the measures covered by the EHII data may be inaccurate in countries where the inequality characteristics of the industrial sector are not representative for the whole income distribution. Although the EHII dataset has been shown to capture trends in inequality in a very reliable manner, it is known to partly fail at capturing volatility in capital income for top percentiles of the income distribution (see e.g. Galbraith et al., 2014). These caveats should be kept in mind when interpreting the results of our estimation.

Our analysis concentrates on a panel of developed industrialized countries, for which relatively long time series of inequality data are available. All member states of the OECD and all countries that are classified as an advanced economy by the $\mathrm{IMF}^{2}$ for which data are available are included in the analysis. The group of 32 countries is composed by Australia, Austria, Belgium, Canada, Chile, Czech Republic, Denmark, Finland, France, Germany, Greece, Hungary, Iceland, Ireland, Israel, Italy, Japan, South Korea, Luxembourg, Mexico, Netherlands, New Zealand, Norway, Poland, Portugal, Slovak Republic, Slovenia, Spain, Sweden, Turkey, United Kingdom and the United States. ${ }^{3}$

The overall dynamics of inequality for the full sample of industrialized countries used in our analysis are depicted in Figure 1 presenting the average Gini index for the 32 countries. Figure 1 shows both the unweighted average and the population-weighted average of Gini indices. Figure 2, on the other hand, shows the values of the inequality index by country. ${ }^{4}$

The average level of inequality in developed countries has risen since the beginning of the eighties, while the population-weighted average indicates that such an increase started in the mid-sixties if we take into account that relatively large countries increased their Gini index already prior to the birth of this global trend. The variation of the Gini index between countries exceeds that within countries, although the statistics in Table A2 indicate that stark differences are present in the country-specific dynamics of income inequality. While decreases in the Gini index took place in Iceland and Belgium, all other countries experienced changes in the direction

\footnotetext{
${ }^{1}$ See the technical appendix for a brief description of the interpolation method.

${ }^{2}$ The list can be found at: http://www.imf.org/external/pubs/ft/weo/2009/01/weodata/groups.htm.

${ }^{3}$ From the original 39 countries which fulfilled the selection criterion (OECD member state or advanced economy according to the IMF), Hong Kong, Taiwan, Malta, Cyprus, Singapore, Switzerland and Estonia had to be excluded due to missing data. This reduction leaves 32 countries in the panel for which in some cases we have data ranging back to the sixties.

${ }^{4}$ Country-specific descriptive statistics of the inequality measure for the full time period considered are shown in Table A1 (Appendix). Table A2 (Appendix) presents evidence concerning the change in the Gini index since the eighties.
} 
of a more unequal distribution of income across individuals. The most sizeable increases in the Gini index took place in countries in Central and Eastern Europe, and double-digit percentage increases in inequality since the eighties is more the rule than the exception among industrialized economies.

\section{The Drivers of Income Inequality}

In order to specify our empirical model in terms of the choice of explanatory variables, we need to assess the nature of the main drivers of inequality from a theoretical point of view. There is a wide range of theories that pinpoint the causes of income inequality. The central economic theories that study the driving forces of inequality dynamics tend to relate to one of three different broad explanatory factors: (a) technological change, that affects inequality through its effect on the skill premium; (b) international trade, which changes relative product prices and thus the wage distribution and (c) the consequences of changes of the political institutions and political conditions.

\subsection{Technological Change}

The seminal paper by Kuznets (1955) analyses the dynamics of inequality during the transition from an agricultural to an industrialized economy. The argument following this view points out that inequality rose when the transition to industrialization set in. The industrialization process leads to a large demand for high-skilled entrepreneurs and engineers, who were in short supply at this moment in history. At a later stage of industrialization in the first half of the twentieth century, inequality declined rapidly. Kuznets (1955) explains this phenomenon as a consequence of the general increase in the level of education, which led to a decline of the skill premium and at the same time boosted the productivity of workers. Advances in technology thus increase the demand for high-skilled labour on the one hand and on the other hand provide incentives for investing in education. Jan Tinbergen referred to this phenomenon as the race between education and technology.

Another reason for the rising skill-premium in industrialized countries is related to the declining demand for low-skilled labour. This development takes place as many industrialized countries undergo a transition from industry-based economies to service economies, which itself is partly a consequence of globalized international trade. The declining demand for low-skilled work in manufacturing is at least partly a consequence of rising imports of labour intensive goods from low-income countries. ${ }^{5}$ The influence of factor-biased technological change on factor demand and factor prices is discussed in the framework of labour market models by Krugman (2000), Acemoglu (2002) and Acemoglu (2003).

\subsection{International Trade and Foreign Direct Investment}

International trade and technological change as root causes for income inequality dynamics are intertwined in a way that makes it difficult to distinguish exactly their differential effects. First

\footnotetext{
${ }^{5}$ See also Feenstra (1998, pages 41-42).
} 
of all, international trade in its modern form is just possible because of modern technology. Especially developments in transport and communication are prerequisites for modern international trade. Secondly, international trade changes the demand for high-skilled and low-skilled workers in different economies and thereby also alters the skill premium. This is precisely the prediction by standard trade theory following the reasoning of the Heckscher-Ohlin model. It states that a country exports those products that use factors of production which are available in abundance in the economy. This means that labour-abundant developing countries export mostly products that are labour-intensive in production and import products which are skilland capital-intensive in production. The outsourcing of labour-intensive production to low-wage countries therefore causes a lower demand for low-skilled workers and a higher demand for highskilled workers in industrialized economies and rises the skill premium. Location matters thus in the sense that production sites are allocated in a way as to profit from these comparative advantages. Production requiring low skill levels is therefore shifted to low-wage countries. In the framework of the Heckscher-Ohlin model, changes in wages are the consequence of changes in product prices. International trade extends markets, which implies that prices of products that are exported are higher than they would be if that product was not sold in international markets. Product prices of imported goods, in turn, are lower than the national price of the same products would be, which is the reason for trading them.

As international trade has grown extensively - in real terms it has multiplied by 45 between 1949 and 2008 - there is much discussion of adverse effects of this development on the distribution of income. This is a direct prediction of standard trade theory. The Stolper-Samuelson theorem - an immediate corollary of the Heckscher-Ohlin model - predicts that the onset or the intensification of international trade changes factor remunerations. In the framework of a model in which high-skilled labour and low-skilled labour are considered to be two different factors of production this means that the distribution of incomes between these two factors is altered by the intensification of international trade. The reasoning behind this prediction is straightforward: as the prices of imported products fall, the wages in the import-competing sector also fall. In contrast, the rising prices of those goods that are exported cause higher wages in the exporting sectors of the economy. Interestingly, the Stolper-Samuelson theorem states that the translation of product prices to factor prices is not proportional - the resulting dispersion of wages is even greater than the dispersion of the related product prices, ${ }^{6}$ an implication known as the the magnification effect.

The trend of increasing globalization has other effects on the wage structure which go beyond the mechanisms proposed by the Heckscher-Ohlin paradigm. It possibly narrows the room for bargaining and therefore lowers the possible impact of wage bargaining institutions, since they face more elastic labour demand curves, particularly for the low-skilled workers.

\subsection{Political Conditions, Institutions and the Labour Market}

Besides international trade and technological progress, a variety of labour market characteristics have been considered important to explain the dynamics of income distribution. Theorists that incorporate such political conditions and institutions have an understanding of the labour market that goes beyond the interplay of market forces. The level and the dynamics of income

\footnotetext{
${ }^{6}$ See Samuelson (1949).
} 
inequality are thus not only assumed to be determined by market interactions but the market itself is shaped by political agency. In this indirect way, political forces possibly matter for the distribution of incomes. While the political forces that possibly shape labour market structures include a wide variety of institutional characteristics of the labour market and the political sphere, the study of these effects is considerably limited by the availability of appropriate data.

Since the objective of trade unions is to raise the relative wages of their members, unionization dynamics may affect wage dispersion within the economy positively or negatively, depending on what union members would be paid if they were not unionized. Blau and Kahn (1996) note that it is particularly the low-paid jobs that are addressed by unions. In many countries ${ }^{7}$ unions tend to raise wages for the low-paid jobs just as a national minimum wage would. Freeman (1982) shows that wage dispersion within the group of unionized workers is smaller than in the group of non-unionized workers. In this sense, the equalization of the pay of their members is an unambiguous income-equalizing effect of unions. In addition to these direct equalizing effects there is an indirect effect of unions that affects non-unionized workers. Employers of non-unionized workers try to avert the threat of unionization by raising the wage of these workers to the union level. This anticipated wage adoption is referred to as the "threat effect" and is well documented, as the review in Western and Rosenfeld (2011) shows. In addition, while the existence of unions is expected to be related to a more equal distribution of wages, its effect on the distribution of household income is ambiguous. In particular, if unions reduce labour demand and increase non-employment, a higher share of jobless households would lead to raising income inequality. The results in Checchi and Garcia-Peñalosa (2008) and Checchi and Garcia-Peñalosa (2010) point indeed in this direction.

\section{$5 \quad$ Empirical Specification: Explaining Income Inequality Dynamics}

\subsection{The Basic Model}

The basic econometric specification on which we base our inference concerning the drivers of inequality is given by

$$
I N E Q_{i t}=\phi I N E Q_{i, t-1}+\beta^{\prime} \mathbf{x}_{i t}+\mu_{i}+\lambda_{t}+\nu_{i t}
$$

where $I N E Q_{i t}$ is the measure of income inequality of country $i$ in period $t$ and $\mathbf{x}_{i t}$ is a $k$ dimensional vector of explanatory variables, that may be strictly exogenous, predetermined or endogenous covariates. These variables are linked to the inequality variable through the parameters which are collected in the column vector $\beta$. Our model specification assumes countryspecific fixed effects $\left(\mu_{i}\right)$ and global shocks, summarized by period-specific effects $\left(\lambda_{t}\right)$. The remaining shock, $v_{i t}$, is assumed to be an i.i.d. distributed error term with constant variance.

The dynamic structure of the panel data model in (1) implies that there is a built-in correlation between the lagged endogenous variable and the error term that lead to biases if the estimates of the parameters in the model are obtained using least-square methods. Starting with Anderson

\footnotetext{
${ }^{7}$ Austria, Germany, Italy, Sweden, and Switzerland are documented in the study by Blau and Kahn (1996).
} 
and Hsiao (1981) and Anderson and Hsiao (1982), methods based on instrumental variables have been developed to overcome the statistical problems involved in the estimation of (1). The popular dynamic panel data estimator put forward by Arellano and Bond (1991) proposes to use suitably lagged values of $y_{t}$ as instruments in the first-differenced specification in the framework of generalized method of moments (GMM) estimation. The Arellano-Bond estimator is however a suboptimal choice if the variable being explained is highly persistent, since lagged levels of a highly persistent variable are weak instruments for its first difference. Blundell and Bond (1998) propose to consider both the corresponding equation in levels and its first-differenced counterpart to formulate an extended set of overidentifying restrictions for the GMM estimator. The estimator proposed by Blundell and Bond (1998) has become standard when dealing with dynamic panel models of highly persistent variables.

The econometric study is conducted for the aforementioned panel of 32 developed industrialized countries. Panel unit root tests for the dependent variable were undertaken before engaging in the econometric analysis of the causes of inequality. The Im-Pesaran-Shin test (Im et al., 2003) yields a $Z_{\tilde{t}-b a r}$-value of -3.85 , with a corresponding p-value of $0.0001{ }^{8}$ This implies that we consider our panel stationary and, accordingly, we estimate models where the inequality measure enters in levels instead of in first differences.

\subsection{From Theory to Data}

As discussed above, we use Gini index data from the EHII dataset as the dependent variable in our estimated specifications. In order to approximate technological change, we use data from Heston et al. (2011) to calculate total factor productivity (TFP) for all countries in our sample based on a standard Cobb-Douglas production function, $Y_{t}=A_{t} F\left(K_{t}, L_{t}\right)=A_{t} K_{t}^{\alpha} L_{t}^{1-\alpha}$. We use labour force data $\left(L_{t}\right)$ and the standard value of $\alpha$ of 0.3 to retrieve estimates of TFP $\left(A_{t}\right)$ after obtaining estimates of the capital stock $\left(K_{t}\right)$ using the perpetual inventory method. ${ }^{9}$

Trade volume estimates are routinely used as explanatory variables in inequality models in order to quantify the effect of international trade. ${ }^{10}$ Many studies use data on total trade openness (see for example Baccaro, 2011; Reuveny and Li, 2003; Lee and Slotsve, 2001), which are readily available in many datasets. Such data are however probably misleading for the question at hand. The bulk of international trade nowadays is not trade between nations with different factor endowments but intra-industry trade between industrialized countries that feature similar factor endowments. Intra-industrial trade can have very different causes and consequences as compared to inter-industry trade, and can be explained by models that do not account for factor endowments. ${ }^{11}$ Therefore, the part of international trade which is in

\footnotetext{
${ }^{8}$ This is the result for the Dickey-Fuller regression specified without a time trend. Including a time trend increases the $Z_{\tilde{t}-b a r}$-value to -7.50 , for which the corresponding p-value is essentially zero.

${ }^{9}$ As a robustness check, we also reestimated our models using total factor productivity data from the Conference Board dataset. This source provides TFP data for a broad of countries, albeit only ranging back to 1990. The most important results of our analysis are not strongly affected by the use of these alternative estimates of total factor productivity. The results of this robustness test are available from the authors upon request.

${ }^{10}$ For a discussion, see Krugman (2000). Opposing the claim that just prices matter, Krugman (2000) argues that trade volumes represent changes in demand and supply that cause product price changes and just these changes reflect the relation between international trade and income inequality.

${ }^{11}$ The theoretical reasons for intra-industry trade are increasing returns and the search for an enlarged market. See Helpman and Krugman (1987) for a basic reference on the causes and consequences of intra-industry trade.
} 
fact intra-industry trade is not necessarily related to rising income inequality in the way it is predicted by the Stolper-Samuelson theorem. To determine the effects of international trade on income inequality in industrialized countries, we have to utilize data on the volume of imports whose production is low-skilled labour intensive and exports whose production is high-skilled labour intensive. As such, these data are not readily available. Rueda and Pontusson (2000), for instance, propose to use data on imports from least developed countries (LDCs), which is actually available from the OECD, albeit only starting in 1980. It can be argued, however, that grouping all developing countries as the relevant aggregate may not be precise enough. Several of the LDCs included are primarily exporters of raw materials (e.g. Saudi Arabia, the Islamic Republic of Iran, Venezuela or Equatorial Guinea). As trade in raw materials is not due to different factor-endowments, it is not theoretically related to the dynamics predicted by the Stolper-Samuelson theorem.

In order to overcome these shortcomings, we calculate the relevant international trade variable using the Bilateral Trade (v2.01) Dataset of the Correlates of War (COW) Project. This dataset contains information on bilateral trade volumes for a vast panel of countries from 1870 to 2006 . We concentrate on trade between the developed countries in our sample and those LDCs that are not major oil exporters or whose exports are not predominately raw materials and mineral resources. The data on export composition which is necessary for this exercise are obtained from Isham et al. (2005), who classify countries by their export structure and identify those countries that predominantly export raw materials. Four major oil producing countries which are not studied in Isham et al. (2005) (Russia, Kuwait, Libya and the United Arab Emirates) are added to the list. The reduced list of LDCs that are not predominantly exporters of crude materials contains 101 countries. An observation of the relevant trade variable for a given year and a given industrialized country is the sum of imports from all of these 101 countries to the corresponding developed economy, normalized by the GDP of the importing economy. This sample of countries is denoted as 'developing countries, no oil' throughout this study.

The Stolper-Samuelson theorem does not only consider the impact of imports but also the effects of exports. Therefore we also calculated the exports of our sample of developed countries to all developing countries. Figure 3 gives an overview of the magnitude of imports from developing countries. As an FDI measure, we employ data on inward and outward FDI stocks as a percentage of GDP that are sourced from the United Nation's World Investment Report.

- Include Figure 3 here -

Since the institutional setting - and in particular institutions related to the labour market - has been proposed as an important determinant of inequality, we use variables which summarize such information in our empirical specification. Union density data are used to proxy for the power of unions. Data on union density for 34 countries ranging from 1960 to 2007 are available from the Database on Institutional Characteristics of Trade Unions, Wage Setting, State Intervention and Social Pacts - (ICTWSS). As the dataset has some missing values, we complemented it with data sourced from the OECD.

Autocratic regimes have the possibility to concentrate wealth and income in their government circles. It can be argued that democratic regimes are more likely to provide for most members of the society. We control for such political institutions using the measure of democracy (polity2) from the Polity-IV dataset. The degree of interference of the state into the economy is measured 
making use of the total tax share of GDP or, alternatively, the share of public expenditures on GDP. Unemployment data from Armingeon et al. (2010) and Armingeon and Romana (2007) are used, as well as data on female labour participation which are sourced from the OECD's Labour Force Statistics (MEI).

In addition to the theoretical forces put forward in Section 3, other determinants of the wage structure need to be controlled for when assessing the driving forces of income inequality dynamics. Inflation possibly increases inequality, as it induces divergence between persistent and fast-adapting wages. The data on inflation were obtained from the World Bank's World Development Indicators dataset. We also control for the effects that the average level of income in a country has on inequality using PPP-adjusted income per capita sourced from Heston et al. (2011). We further control for business cycle dynamics by including GDP growth as a covariate in the specification - the data are again from Heston et al. (2011).

In order to assess the effects of immigration on income distribution dynamics, we control for net migration - the number of immigrants minus the number of emigrants - as a share of total population. Data originating from the OECD and Eurostat are taken from Samanni et al. (2010). ${ }^{12}$ An important control variable is the level of education of the population. Data on mean years of schooling for the population aged 15 and above from the Barro-Lee database are used for this purpose. In addition, data on population growth and the dependency ratio are sourced from the World Development Indicators.

\section{Estimation Results}

\subsection{Inequality and International Trade}

We start by investigating the link between international trade and inequality. Table 1 presents seven estimated models which differ solely on the international trade variable that is included in the model (imports from developing economies excluding oil exporters, imports from developing economies, total imports, exports to developing economies, total exports and total trade, all normalized by GDP).

In addition to the corresponding trade variable and the lag of the dependent variable, our models include three measures to capture the macroeconomic conditions of the economy: the GDP per capita, its square and GDP per capita growth. Two further control variables are included in the baseline specification: the total tax share of GDP and the mean years of schooling of the population over 15. All explanatory variables are lagged by one year. The models are estimated using system-GMM methods. GDP per capita, its square and GDP per capita growth are considered endogenous and are instrumented by one further lag in the framework of the GMM estimation of the model. ${ }^{13}$

- Include Table 1 here -

\footnotetext{
${ }^{12}$ If data from the OECD and Eurostat were available, we calculate the average. If none of these two sources are available, data are taken from the World Development Indicators.

${ }^{13}$ We decided to keep a relatively small set of instruments in our estimation. Enlarging the set improves the results of the Sargan test but does not affect our conclusions significantly. Results are available from the authors upon request.
} 
Columns 1 to 6 in Table 1 show the estimation results for the baseline model extended by our six different trade measures. Of all of the trade variables that are positively and significantly related to income inequality the impact of imports from non-oil-exporting LDCs is the largest among all trade covariates. Our results in Table 1 indicate that, as predicted by the Heckscher-Ohlin model and the Stolper-Samuelson theorem, trade with developing countries in fact worsens the income distribution (that is, increases the Gini index) in developed countries. Imports from all LDCs have a smaller and less significant impact on the wage distribution, with a coefficient which is just significant at the $10 \%$ level and an impact on inequality corresponding to a $6 \%$ increase in the Gini index relative to its standard deviation if LDC imports rise by one standard deviation. For the same relative change in imports from non-oil-exporting LDCs inequality increases by roughly $25 \%$ of its standard deviation. The exclusion of raw material exporting countries appears thus crucial and unveils a sizeable effect of imports on inequality as predicted by theory.

Overall trade openness appears highly significant but has a quantitatively much smaller influence on inequality. This highly aggregated measure seems to obscure the theoretical working of the impact of trade on inequality and only raises inequality by $8 \%$ of its standard deviation when it rises by one standard deviation. In column 7 we present the estimates of the model with trade openness as an explanatory variable using fixed-effects OLS, which also confirm the results of the GMM estimation concerning the effect of this variable.

None of the covariates relating to the economic development of the economy have a robust impact on the dynamics of income inequality. The parameter estimates for the linear and squared terms of GDP per capita, included to check for the nonlinear effect predicted by Kuznets (1955), do not confirm an inverse U-shaped relationship between income and inequality. ${ }^{14}$

- Include Table 2 here -

Table 2 shows the results for alternative specifications of the model including the variable which measures imports from non-oil-exporting LDCs. In columns 1 to 3 we present the results of smaller models, while the model in column 4 corresponds to the specification in column 1 of table 1. In column 5 we present the results of a model where we substitute the tax share of GDP for the share of public expenditures on GDP. The effect of a change in the government size covariate is qualitatively similar across these two variables and the change in the specification does not affect the rest of the results strongly. ${ }^{15}$ The results presented in column 6 correspond to a model extended by including (the lagged level of) union density and inflation, as well as FDI variables. Inflation and union density have significant effects that correspond to the mechanisms expected from a theoretical perspective. More unionized labour markets tend to be related to less inequality, while higher inflation tends to increase the Gini index. In spite of the fact that we lose an important part of our sample by using these two covariates in the

\footnotetext{
${ }^{14}$ It should be noted that in many specifications the $\operatorname{AR}(2)$ test gives evidence of second-order autocorrelation in the residuals of the first-differenced model. This result is driven by the observations at the beginning of the sample, as was confirmed by reestimating the models for subsamples. The main results of the analysis remain unchanged if the sample is restricted to the last two decades, where the $\operatorname{AR}(2)$ test is not significant. This makes us confident that the linkages unveiled in our empirical analysis are indeed robust and not just driven by potentially misspecified regression models.

${ }^{15}$ Given the larger coverage of the tax share data, we stick to this measure of government size for the rest of the specifications.
} 
specification, their inclusion does not qualitatively change our conclusions concerning the effects of the trade variable. We lose more than half of our sample when we include FDI variables in the model. The size and significance of the effect of our trade variable in this specification are reduced, but it remains significant at the $10 \%$ level. A marginally significant effect of FDI inward stocks implying that more FDI leads to more inequality is also present in the data.

Our clear-cut results concerning the effect of trade on inequality contrast with the estimates of other studies which assess the same relationship. Lundberg and Squire (2003), Baccaro (2011) and Figini and Görg (2011) do not find a strong influence of trade on inequality employing trade openness as an independent variable. Reuveny and Li (2003) also employ overall trade openness as a regressor and find a significantly income-equalizing effect of trade for their global sample as well as for two subsamples of developing and OECD countries, although the effect is quantitatively rather small (if trade openness rises by one standard deviation, the Gini index is reduced by $14.22 \%$ of its standard deviation). Jaumotte et al. (2008) find that an increase in the export-to-GDP ratio reduces inequality while the share of imports on GDP is insignificant. By narrowing their sample and only including developed economies, they find that a rising share of imports from developing countries reduces inequality. Mahler (2004) finds that imports from LDCs and other measures of globalization are not significantly related to wage inequality. This finding is similar to that of Rueda and Pontusson (2000) and Oliver (2008), who both find that the degree of openness with less developed countries is not significantly associated to the dynamics of wage inequality in OECD countries. Beramendi and Cusack (2008) study the effect of LDC imports on wage inequality in OECD countries and find the opposite effect as theory would predict. Dreher and Gaston (2008) focus on the question on whether globalization has increased inequality and employ the KOF-index as a measure of globalization. They find that a rise of this index is significantly associated with a rise of inequality. The effects of globalization on within-country inequality are also analyzed by Bussmann et al. (2005). Their primary focus is the influence of FDI and they do not find a link between its dynamics and inequality. In addition to this, the coefficients of both of their trade related measures are not significantly different from zero. For these reasons, they conclude that globalization has in fact not adversely affected national income inequality.

The fact that international trade for developed countries is to a large extent intra-industrial trade explains such results and the difference with our estimates using only trade with nonoil-exporting LDCs. The same applies to the pooling of all developing countries as trading partners without making an explicit difference between exporters of raw materials and countries which are specialized in low-wage manufactured goods. The study by Pontusson et al. (2002) gets closer to our definition of the trade variable. They use data on imports from LDCs and exclude from this panel the OPEC member states. Their results, however, do not confirm a significant positive relationship between inequality and trade. The use of different time periods has also strong effects on the nature of the association found. Reestimating our model for two subperiods (pre-1990 and post-1990) results on significant and strong effects only for the more recent subsample. ${ }^{16}$

\footnotetext{
${ }^{16}$ It should be noted that the poor results on identifying the relationship implied by the Stolper-Samuelson theorem in previous studies might also be due to inappropriate estimation strategies. Many studies do not take advantage of up-to-date dynamic panel data estimators and studies which do so either do not include trade flows as a independent variable (as Calderón et al., 2005) or use data with an a priori relatively low information signal (as Dreher and Gaston, 2008), who employs an aggregated index of globalization).
} 
The study by Meschi and Vivarelli (2009) can be seen as complementary to our study since it is methodologically and theoretically closely related but in contrast to our study concentrates on the dynamics of inequality in developing countries. Meschi and Vivarelli (2009) present evidence based on 65 developing countries over the period spanning the eighties and nineties and find that imports from and exports to developed countries significantly worsen the income distribution in middle-income countries.

- Include Table 3 here -

Table 3 show the estimation results from models that include further control variables. The inclusion of the dependency ratio, population growth and immigration does not alter the results qualitatively and the variables themselves do not affect inequality in a statistically significant manner. We furthermore find an insignificant effect of technological progress as measured by the Solow residual. In Table 4, we provide the estimation results of models where we move away from pure linear effects of technology and education by including also an interaction term between these variables. Such an interaction can be thought of as modelling Tinberger's "race between education and technology". The results indicate that the negative effect of education on the inequality measure is reduced in economies with relatively high total factor productivity, thus lending support that the joint dynamics of productivity and skilled labour are able to partly explain changes in the Gini index over the sample studied. The sign of the estimated parameters show that in relatively underdeveloped economies (in terms of total factor productivity), the income-equalizing effects of education are stronger than in highly developed countries.

- Include Table 4 here -

In further model specifications which were estimated but are not shown, we find that changes of the unemployment rate are not associated with the dynamics of inequality. This confirms the results in other studies (Oliver (2008), for instance) and can be explained by two countervailing effects that cancel each other out. On the one hand rising unemployment puts higher pressure on low income workers as their bargaining power diminishes and their wages are kept low, thus increasing inequality. On the other hand, rising unemployment is likely to imply that formerly low wage workers become unemployed. In this sense, increases in unemployment could be associated with a reduction of inequality among wage earners. ${ }^{17}$

\subsection{Inequality and Democratization}

Table 5 on page 27 shows in its first column the results of a model that includes the level of democracy as an extra regressor in our specification, using the polity 2 variable from the PolityIV dataset. This variable ranges from -10 (authoritarian regime) to +10 (democratic regime) and was transformed to the range $[0,10]$. The estimated negative coefficient for the variable indicates that democratization goes along with decreasing inequality. Dreher and Gaston (2008), on the contrary, find that democratization is related to a rise in income inequality. They justify these results arguing that an increase in democracy is associated with market-oriented reforms, which increase inequality.

\footnotetext{
${ }^{17}$ These results are available from the authors upon request.
} 
These contradictory results regarding the relationship between democracy and income inequality can be better understood by assessing empirically the effects of changes in the political regime for different groups of countries. We classified all the countries into three different groups. All former members of the Warsaw Pact and their successor states were grouped together (Hungary, Poland, the Slovak Republic and the Czech Republic), a second group comprises all countries from Western Europe (Iceland, Austria, Belgium, Denmark, Finland, France, Germany, Greece, Ireland, Italy, Slovenia, Luxembourg, Malta, Netherlands, Norway, Portugal, Spain, Sweden, Switzerland and United Kingdom) and the remaining countries are subsumed to a third group. ${ }^{18}$

For the Western European group, four countries were not always considered to be fully democratic in the sense of the polity2 index: Portugal, Spain, France and Greece. France was never rated 10 after 1958 primarily because of weak "executive constraints" (see http://www . systemicpeace.org/polity/France2008.pdf). The other three countries underwent drastic democratization processes over our observation period. Portugal was rated -9 in 1973 and after the Carnation Revolution in 1974 and the end of the authoritarian dictatorship of the Estado Novo under Antonio de Oliveira Salazar, the political regime was rated with 9 as of 1976. A comparable change of political regime happened in neighboring Spain. Before the death of Francisco Franco, Spain was rated -7 (1973). Three years later, Spain was rated 9 - even before the proclamation of the constitution in 1978. Greece's transition from the dictatorship under Georgios Papadopoulos to a democracy is reflected in the change from - 7 in 1973 to a rating of 8 in 1975. The democratization processes that took place in these countries went hand in hand with a trend towards a more equal distribution of income, as can be seen in Figure 4, which depicts the average Gini index for the three groups described above. Notice that, on the other hand, the strong democratization processes which took place in Eastern Europe happened in parallel to an increase in the Gini index.

\section{- Include Figure 4 here -}

We estimate a model with different parameters attached to the democracy index for each one of these group, which is presented in Table 5. Since there is a possible endogeneity problem because, as Muller (1995) shows, falling levels of inequality make democratization more likely, we specifying the democracy variable as endogenous in the GMM framework in addition to using its lagged value (as with all other covariates). The coefficient for the group of ex-Soviet countries is negative and resembles the results that Dreher and Gaston (2008) find for their entire sample. Our result for this subsample can be interpreted as reflecting the transition from a socialist economy to a market economy, that was accompanied with a rise of the inequality of incomes. This argument is in line with Krugman et al. (1999). Although our result is insignificant for non-European countries, changes in the level of democracy are found to be associated with a decline of inequality for the rest of the countries in our sample.

We also estimated regressions based on specifications that include a political risk indicator. In particular, we use the measures proposed by Kunčič (2014) which are available for the

\footnotetext{
${ }^{18}$ Although Slovenia was not part of the Warsaw Pact, its inclusion in this group could be argued given the political history of the country. The results presented are not influenced by the exclusion of Slovenia of the Warsaw Pact group, as robustness checks that we conducted clearly show. These are available from the author upon request.
} 
period 1990-2003. The results, not shown here but available upon request, show that only improvements in "economic quality", an index which is related to the well-functioning of markets and property rights enforcement, appear to be associated with rising inequality.

\subsection{Inequality and the Size of the State}

The tax share of GDP is a significant determinant of income inequality throughout all specifications. Increases in the variable tend to be robustly associated with decreases of inequality. Several channels explain such a result. A rising share of tax revenue is likely to be associated with an increase in the number of public sector employees and this in turn is likely to contribute to income equalization as the income inequality in the public sector is smaller than in the private sector. This precise relationship - an equalizing effect of higher public sector employment - is found by Calderón et al. (2005) and Pontusson et al. (2002). On the other hand, a rising share of taxes possibly implies a declining incentive to aim for higher incomes as those are increasingly taxed. The tax share of GDP tends to be strongly correlated with regulation of the labour market such as minimum-wage laws ${ }^{19}$ and stronger labour protection. Unemployment benefits are also likely to be higher in states with a larger tax share of GDP. Koeniger et al. (2007) find that more generous unemployment benefits in fact lower income inequality. This can be explained by the higher reservation wage that forces employers to adjust their low wages accordingly. Simple correlation analysis across countries confirms such associations as potential mechanisms driving the effect of government size on inequality.

- Include Table 6 here -

Rueda and Pontusson (2000) analyze the dynamics of inequality separately for what they call Liberal Market Economies (LME) and Social Market Economies (SME). They classify economies as belonging to one or the other category by considering several indicators, including the labour decommodification index. We classify the countries in our sample as belonging to one or the other category relying on their mean tax share of GDP. By considering all countries with a higher mean tax share than $35 \%$ to be SME, actually the same classification as Rueda and Pontusson (2000) is reached. ${ }^{20}$

Estimating separate models for LME and SME (see Table 6), we find that market forces have a much stronger effect on inequality in LME. A change in taxes as share of GDP has only a negative (albeit not significant) effect on inequality in LMEs, where this level tends to be generally low. The lack of significance of the tax share variable in the subsamples can thus be explained by the fact that it is correlated with the dummy variable defining LME and SME. The signal content of the within-group variability in tax shares in each one of the two groups is thus not powerful enough as to lead to significant parameter estimates for this variable. Similarly, it is only in LMEs that an increase of non-oil-producing LDC imports is associated with an

\footnotetext{
${ }^{19}$ The empirical result that rising minimum wages diminish wage inequality is documented in Koeniger et al. (2007).

${ }^{20}$ Rueda and Pontusson (2000) and Esping-Andersen (1990) include less countries in their studies than we do. Rueda and Pontusson (2000) label the following countries as LME: Australia, United States, Canada, Switzerland, Japan and United Kingdom. The following group forms the SME subsample: Germany, Finland, Austria, Belgium, Netherlands, Denmark, Norway, Sweden. Italy and France are labelled as mixed economies.
} 
increase of income inequality. This suggests that SMEs are capable of mitigating the effect of trade on income inequality more efficiently than LMEs. ${ }^{21}$

\subsection{Inequality and the Power of Trade Unions}

Our results concerning an overall income-equalizing effect of trade unions confirm the findings of Mahler (2004), Koeniger et al. (2007) and Beramendi and Cusack (2008). Mahler (2004) finds that higher levels of wage coordination lower inequality and more so when measured as disposable income inequality. Disposable income inequality is additionally lowered by higher levels of union density. Beramendi and Cusack (2008), Koeniger et al. (2007) and Rueda and Pontusson (2000) confirm empirically the influence of unions on inequality. Pontusson et al. (2002) analyze the dynamics of wage inequality in the upper and lower halves of the wage distribution separately and find that higher levels of labour organization through unions is especially raising the relative wages of the low-paid unskilled workers in the lower half of the distribution.

\section{- Include Table 7 here -}

Following Baccaro (2011), we take a step further and study potential changes in the effect of unionization on income distribution over time. In the context of shrinking numbers of unionized workers and of rising globalization, it has been argued that internationalization renders labour demand curves more elastic, which increasingly lowers the bargaining power of unions. We estimate a model in which time dummies - for each one of the periods in our sample - are interacted with the union density variable. Our results, presented in column 1 of Table 7, indicate that in parallel to the loss of bargaining power throughout the 40 year period of the study, a rise in union density is less significantly linked to a decline of inequality. In column 2 of the same table the results of a model that analyzes the impact of non-oil-exporting LDC imports over time are shown. In contrast to the effect of unions, the effect of trade increases over time, becoming significant in the early nineties and the strongest in the last years of the sample.

\section{Conclusions}

We present a fully-fledged empirical analysis of the determinants of income inequality in the developed world, using the widest-ranging panel dataset available and a multitude of potential determinants implied by theory. As such, this study takes a comprehensive approach to unveiling the drivers of inequality in the developed world and thus improves on the existing literature, which tends to concentrate on individual drivers.

The main finding of our empirical analysis is that low-wage imports to developed countries tend to worsen income inequality. This finding is very robust and the variation in the trade variable explains a large fraction of the within-country variation of income inequality. As opposed

\footnotetext{
${ }^{21}$ This result is not driven by differences in the overall openness of the countries in the two subsamples. The variability of the trade variable is comparable across subgroups.
} 
to most of the other contributions to the literature, our analysis concentrates on a variable which is constructed in such a way as to mimic the type of trade flows which are implied by the theoretical setting of the Heckscher-Ohlin model. The Stolper-Samuelson theorem as a corollary of the Heckscher-Ohlin model predicts this result, thus our study confirms the standard prediction of trade theory.

In addition, we find that government size, the interaction of technology and education, democratization processes and the reshaping of the labour market by unions have played an important role in explaining the dynamics of income inequality in the developed world over the last decades. In addition, the effect of government size appears to be particularly relevant for liberal market economies. While the size of the effect of unionization has decreased over time, income inequality tends to react more strongly to international trade in the recent past. 


\section{References}

Acemoglu, D. (2002). Technical change, inequality, and the labor market. Journal of Economic Literature 40(1), 7-72.

Acemoglu, D. (2003). Patterns of skill premia. Review of Economic Studies 70(2), 199-230.

Anderson, T. W. and C. Hsiao (1981). Estimation of dynamic models with error components. Journal of the American Statistical Association 76(375), 598-606.

Anderson, T. W. and C. Hsiao (1982). Formulation and estimation of dynamic models using panel data. Journal of Econometrics 18(1), 47-82.

Arellano, M. and S. Bond (1991). Some tests of specification for panel data: Monte carlo evidence and an application to employment equations. Review of Economic Studies 58(2), $277-297$.

Armingeon, K., S. Engler, P. Potolidis, M. Gerber, and P. Leimgruber (2010). Comparative political data set 1960-2008. Institute of Political Science, University of Berne.

Armingeon, K. and C. Romana (2007). Comparative data set for 28 post-communist countries, 1989-2007. Institute of Political Science, University of Berne.

Atkinson, A. B. and A. Brandolini (2001). Promise and Pitfalls in the Use of 'Secondary' Data-Sets: Income Inequality in OECD Countries as a Case Study. Journal of Economic Literature 39(3), 771-799.

Baccaro, L. (2011). Labor, globalization and inequality: Are trade unions still redistributive? Research in the Sociology of Work 22, 213-285.

Beramendi, P. and T. R. Cusack (2008). Diverse disparities: The politics and economics of wage, market, and disposable income inequalities. Political Research Quarterly 62(2), 257-275.

Blau, F. D. and L. M. Kahn (1996). International differences in male wage inequality: Institutions versus market forces. Journal of Political Economy 104(4), 791-837.

Blundell, R. and S. Bond (1998). Initial conditions and moment restrictions in dynamic panel data models. Journal of Econometrics 87(1), 115-143.

Bussmann, M., I. De Soysa, and J. R. Oneal (2005). The effect of globalization on national income inequality. Comparative Sociology 3, 285-312.

Calderón, C., A. Chong, and R. O. Valdés (2005). Labor market regulations and income inequality: Evidence for a panel of countries. Central Banking, Analysis, and Economic Policies Book Series, 221-279.

Checchi, D. and C. Garcia-Peñalosa (2008). Labour market institutions and income inequality. Economic Policy 23, 601-649.

Checchi, D. and C. Garcia-Peñalosa (2010). Labour Market Institutions and the Personal Distribution of Income in the OECD. Economica 777(307), 413-450. 
Deininger, K. and L. Squire (1996). A new data set measuring income inequality. World Bank Economic Review 10(3), 565-91.

Dreher, A. and N. Gaston (2008). Has globalization increased inequality? Review of International Economics 16(3), 516-536.

Esping-Andersen, G. (1990). The Three Worlds of Welfare Capitalism. Princeton University Press.

Feenstra, R. C. (1998). Integration of trade and disintegration of production in the global economy. Journal of Economic Perspectives 12(4), 31-50.

Figini, P. and H. Görg (2011). Does foreign direct investment affect wage inequality? an empirical investigation. World Economy 34(9), 1455-1475.

Freeman, R. (1982). Union wage practices and wage dispersion within establishments. Industrial and Labor Relations Review 36(1), 3-21.

Galbraith, J. K., B. Halbach, A. Malinowska, A. Shams, and W. Zhang (2014). The UTIP Global Inequality Data Sets 1963-2008. Updates, Revisions and Quality Checks. UTIP Working Paper 68.

Galbraith, J. K. and H. Kum (2005). Estimating the inequality of household incomes: A statistical approach to the creation of a dense and consistent global data set. Review of Income and Wealth 51(1), 115-143.

Hall, P. A. and D. Soskice (2001). Varieties of Capitalism: The Institutional Foundations of Comparative Advantage. Oxford University Press.

Helpman, E. and P. Krugman (1987). Market Structure and Foreign Trade: Increasing Returns, Imperfect Competition, and the International Economy. The MIT Press.

Heston, A., R. Summers, and B. Aten (2011). Penn world table version 7.0. Center for International Comparisons of Production, Income and Prices at the University of Pennsylvania.

Im, K. S., M. H. Pesaran, and Y. Shin (2003). Testing for unit roots in heterogeneous panels. Journal of Econometrics 115(1), 53-74.

Isham, J., M. Woolcock, L. Pritchett, and G. Busby (2005). The varieties of resource experience: Natural resource export structures and the political economy of economic growth. World Bank Economic Review 19(2), 141-174.

Jaumotte, F., S. Lall, and C. Papageorgiou (2008). Rising income inequality: Technology, or trade and financial globalization? International Monetary Fund Working Papers 08(185).

Koeniger, W., M. Leonardi, and L. Nunziata (2007). Labour market institutions and wage inequality. Industrial and Labor Relations Review 60(3), 340-356.

Krugman, P. (2000). Technology, trade and factor prices. Journal of International Economics $50(1), 51-71$. 
Krugman, P., B. P. Bosworth, and R. N. Cooper (1999). Domestic policies in a global economy. Brookings Trade Forum, 73-103.

Kunčič, A. (2014). Institutional quality dataset. Journal of Institutional Economics 10(01), $135-161$.

Kuznets, S. S. (1955). Economic growth and income inequality. American Economic Review 45, $1-28$.

Lee, W. and G. A. Slotsve (2001). Globalization, world democratization, and the dynamics of income distribution across nations. Northern Illinois University.

Lundberg, M. and L. Squire (2003). The simultaneous evolution of growth and inequality. Economic Journal 113(487), 326-344.

Mahler, V. A. (2004). Economic globalization, domestic politics, and income inequality in the developed countries: A cross-national study. Comparative Political Studies 37(9), 1025-1053.

Meschi, E. and M. Vivarelli (2009). Trade and income inequality in developing countries. World Development 37(2), 287-302.

Muller, E. N. (1995). Economic determinants of democracy. American Sociological Review $60(6), 966-982$.

Oliver, R. (2008). Diverging developments in wage inequality: Which institutions matter? Comparative Political Studies 41, 1551-1582.

Pinkovskiy, M. L. (2013). World welfare is rising: Estimation using nonparametric bounds on welfare measures. Journal of Public Economics 97, 176-195.

Pontusson, J., D. Rueda, and C. R. Way (2002). Comparative political economy of wage distribution: The role of partisanship and labour market institutions. British Journal of Political Science 32(02), 281-308.

Reuveny, R. and Q. Li (2003). Economic openness, democracy, and income inequality. Comparative Political Studies 36(5), 575-601.

Rueda, D. and J. Pontusson (2000). Wage inequality and varieties of capitalism. World Politics 52(3), 350-383.

Sala-i Martin, X. (2006). The World Distribution of Income: Falling Poverty and ... Convergence, Period. Quarterly Journal of Economics 121(2), 351-397.

Samanni, M., J. Teorell, S. Kumlin, and B. Rothstein (2010). The QoG social policy dataset, version 11nov10. University of Gothenburg: The Quality of Government Institute http://www.qog.pol.gu.se.

Samuelson, P. A. (1949). International factor-price equalisation once again. Economic Journal 59(234), 181-197.

Western, B. and J. Rosenfeld (2011). Unions, norms, and the rise in U.S. wage inequality. American Sociological Review 76(4), 513-537. 


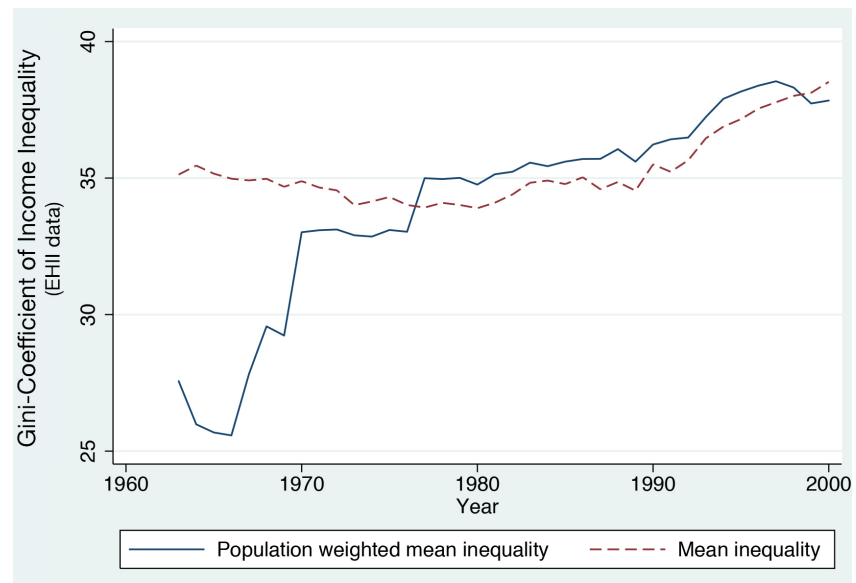

Figure 1: Average Gini index (EHII dataset) for 32 developed economies. Unweighted average versus population-weighted average.

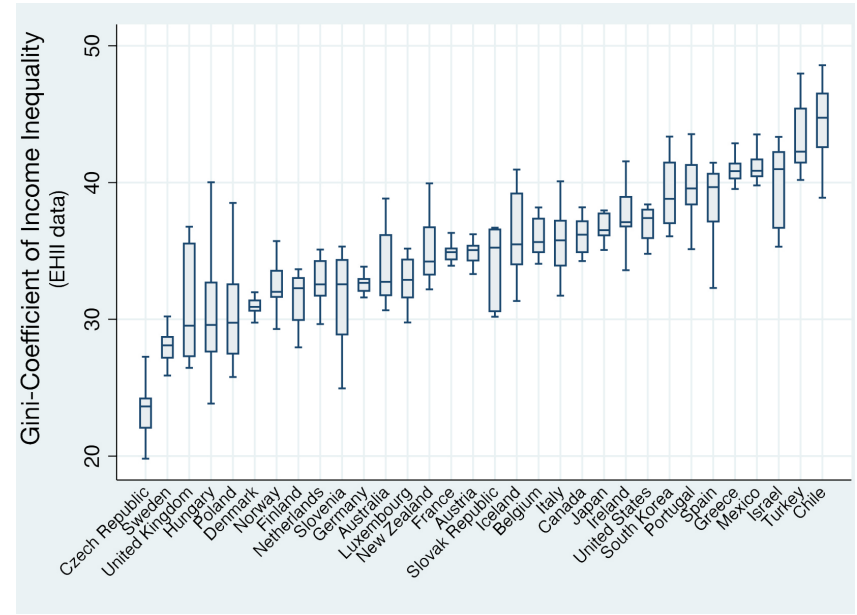

Figure 2: Gini index (EHII dataset) for 32 developed economies. Countries ascending by median inequality. 


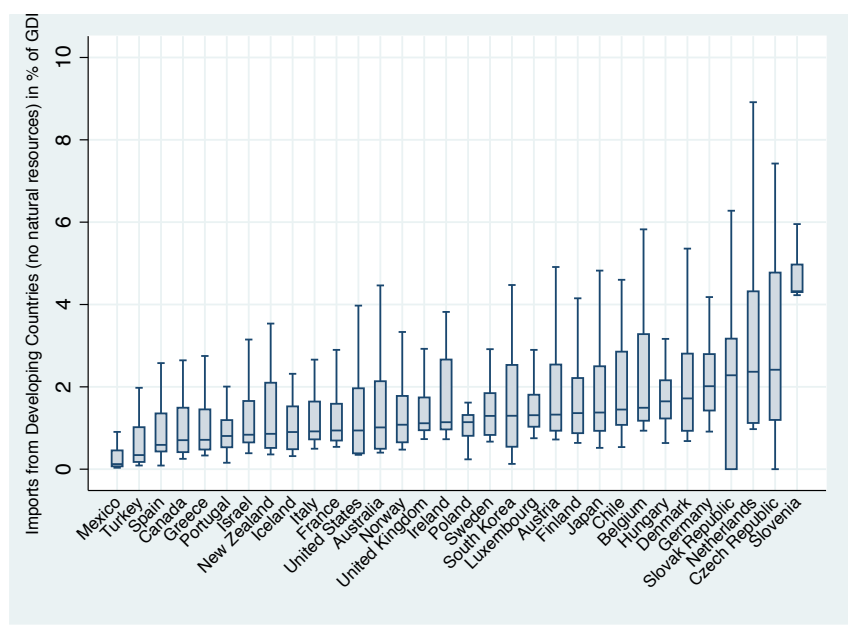

Figure 3: Imports from LDCs (without oil and raw material exporters) as \% of GDP.

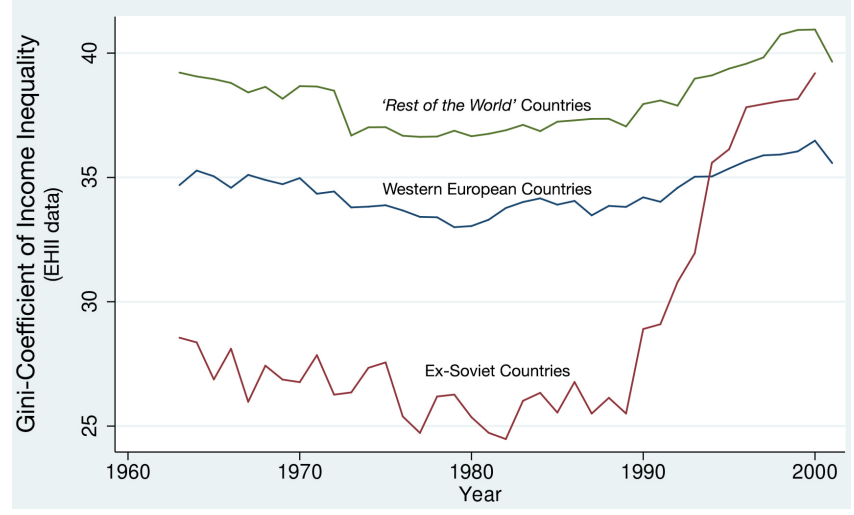

Figure 4: Mean Gini index for different groups of countries 
Table 1: Baseline model with different trade variables

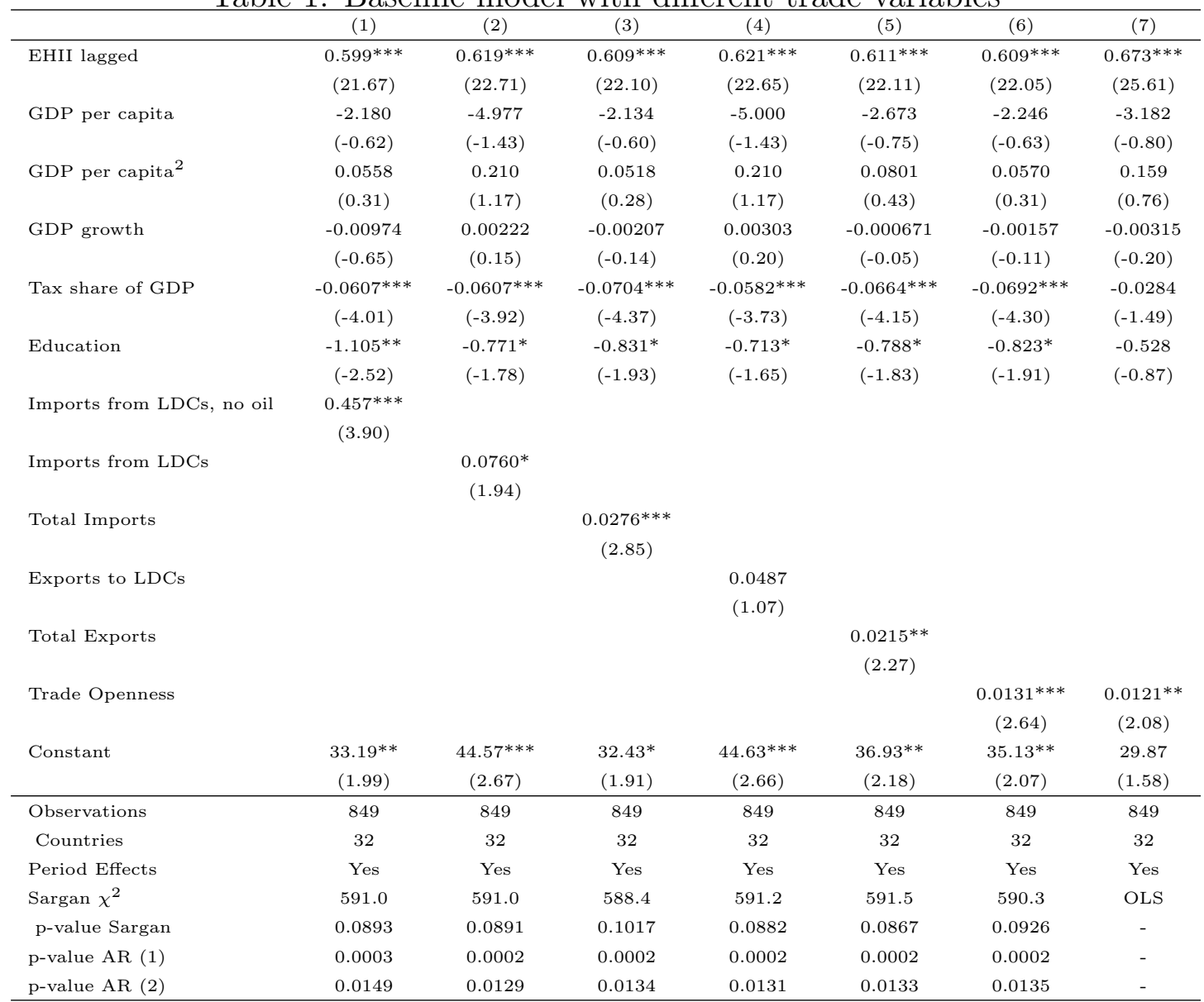

$\left(^{*}\right),\left[{ }^{* *}\right],\left\{{ }^{* * *}\right\}$ indicate significance at the $(10 \%),[5 \%],\{1 \%\}$ level respectively. Estimation by System-GMM. Dependent variable is the Gini index from Estimated Household Income Inequality (EHII). z-values in brackets. AR (1) and AR (2) refer to the p-value test statistic for first- and second-order autocorrelation on the disturbances of the first-differences equations. p-value Sargan is the p-value of the test statistic for the validity of the overidentifying restriction. Decade dummies included in all models. 
Table 2: Alternative specifications of the baseline model

\begin{tabular}{|c|c|c|c|c|c|c|c|}
\hline & $(1)$ & $(2)$ & $(3)$ & $(4)$ & $(5)$ & $(6)$ & $(7)$ \\
\hline \multirow[t]{2}{*}{ EHII lagged } & $0.622^{* * *}$ & $0.577^{* * *}$ & $0.442^{* * *}$ & $0.599^{* * *}$ & $0.628 * * *$ & $0.562 * * *$ & $0.564^{* * *}$ \\
\hline & {$[18.71]$} & {$[16.22]$} & {$[10.80]$} & {$[21.67]$} & {$[18.89]$} & {$[20.96]$} & {$[17.29]$} \\
\hline \multirow[t]{2}{*}{ GDP per capita } & & & & -2.180 & -4.868 & $-5.605^{*}$ & -6.515 \\
\hline & & & & {$[-0.62]$} & {$[-0.95]$} & {$[-1.69]$} & {$[-0.86]$} \\
\hline \multirow[t]{2}{*}{ GDP per capita ${ }^{2}$} & & & & 0.0558 & 0.184 & 0.253 & 0.327 \\
\hline & & & & {$[0.31]$} & {$[0.69]$} & {$[1.45]$} & {$[0.82]$} \\
\hline \multirow[t]{2}{*}{ GDP growth } & & & & -0.00974 & 0.000946 & -0.00693 & 0.00144 \\
\hline & & & & {$[-0.65]$} & {$[0.04]$} & {$[-0.43]$} & {$[0.07]$} \\
\hline \multirow[t]{2}{*}{ Education } & & & & $-1.105^{* *}$ & -1.309 & -0.478 & $-1.514^{* *}$ \\
\hline & & & & {$[-2.52]$} & {$[-1.45]$} & {$[-0.90]$} & {$[-2.23]$} \\
\hline \multirow[t]{2}{*}{ Tax share of GDP } & & & $-0.169 * * *$ & $-0.0607 * * *$ & & -0.0242 & $-0.0439 * *$ \\
\hline & & & {$[-7.54]$} & {$[-4.01]$} & & {$[-1.62]$} & {$[-2.49]$} \\
\hline Public Expenditure & & & & & $-0.0334^{* * *}$ & & \\
\hline Share of GDP & & & & & {$[-4.08]$} & & \\
\hline Imports from LDCs, & & $0.408^{* * *}$ & $0.753^{* * *}$ & $0.457^{* * *}$ & $0.221 *$ & $0.330^{* * *}$ & $0.238^{*}$ \\
\hline no oil & & {$[3.11]$} & [5.19] & {$[3.90]$} & {$[1.68]$} & {$[2.85]$} & {$[1.72]$} \\
\hline \multirow[t]{2}{*}{ Union density } & & & & & & $-0.0309^{* * *}$ & $-0.0270 * * *$ \\
\hline & & & & & & {$[-5.13]$} & {$[-3.71]$} \\
\hline \multirow[t]{2}{*}{ Inflation } & & & & & & $0.0282^{* * *}$ & $0.0246 * * *$ \\
\hline & & & & & & {$[4.74]$} & [3.73] \\
\hline \multirow[t]{2}{*}{ FDI Stock Inward } & & & & & & & $0.0157^{*}$ \\
\hline & & & & & & & {$[1.70]$} \\
\hline \multirow[t]{2}{*}{ FDI Stock Outward } & & & & & & & -0.0148 \\
\hline & & & & & & & {$[-0.88]$} \\
\hline \multirow[t]{2}{*}{ Constant } & $14.42^{* * *}$ & $15.33^{* * *}$ & $25.22^{* * *}$ & $33.19^{* *}$ & $46.96^{*}$ & $49.39 * * *$ & 53.99 \\
\hline & [11.57] & [11.62] & {$[12.85]$} & [1.99] & {$[1.89]$} & {$[3.07]$} & {$[1.47]$} \\
\hline Observations & 1075 & 1031 & 850 & 849 & 564 & 744 & 447 \\
\hline Countries & 32 & 32 & 32 & 32 & 32 & 30 & 29 \\
\hline Period Effects & Yes & Yes & Yes & Yes & Yes & Yes & Yes \\
\hline Sargan $\chi^{2}$ & 226.3 & 231.4 & 190.0 & 591.0 & 378 & 725.3 & 530.1 \\
\hline p-value Sargan & 0.0000 & 0.0000 & 0.0000 & 0.0893 & 0.0142 & 0.1162 & 0.0529 \\
\hline p-value AR (1) & 0.0005 & 0.0006 & 0.0002 & 0.0003 & 0.0029 & 0.0004 & 0.0007 \\
\hline p-value AR (2) & 0.0650 & 0.0369 & 0.0140 & 0.0149 & 0.1296 & 0.0453 & 0.0852 \\
\hline
\end{tabular}

$(*),[* *],\{* * *\}$ indicate significance at the $(10 \%),[5 \%],\{1 \%\}$ level respectively. Estimation by System-GMM. Dependent variable is the Gini index from Estimated Household Income Inequality (EHII). z-values in brackets. AR (1) and AR (2) refer to the p-value test statistic for first- and second-order autocorrelation on the disturbances of the first-differences equations. p-value Sargan is the p-value of the test statistic for the validity of the overidentifying restriction. Decade dummies included in all models. 
Table 3: Alternative specifications with further control variables

\begin{tabular}{|c|c|c|c|c|}
\hline & 1 & 2 & 3 & 4 \\
\hline \multirow[t]{2}{*}{ EHII lagged } & $0.564^{* * *}$ & $0.561^{* * *}$ & $0.563^{* * *}$ & $0.561^{* * *}$ \\
\hline & {$[20.92]$} & {$[20.92]$} & {$[20.92]$} & {$[20.81]$} \\
\hline \multirow[t]{2}{*}{ GDP per capita } & -4.684 & -4.656 & -5.383 & -5.433 \\
\hline & {$[-1.24]$} & {$[-1.30]$} & {$[-1.60]$} & {$[-1.63]$} \\
\hline \multirow[t]{2}{*}{ GDP per capita ${ }^{2}$} & 0.208 & 0.201 & 0.239 & 0.231 \\
\hline & {$[1.07]$} & {$[1.07]$} & [1.35] & {$[1.28]$} \\
\hline \multirow[t]{2}{*}{ GDP growth } & -0.00479 & -0.00548 & -0.00712 & -0.00975 \\
\hline & {$[-0.30]$} & {$[-0.34]$} & {$[-0.44]$} & {$[-0.60]$} \\
\hline \multirow[t]{2}{*}{ Education } & -0.466 & -0.505 & -0.489 & -0.485 \\
\hline & {$[-0.87]$} & {$[-0.94]$} & {$[-0.92]$} & {$[-0.91]$} \\
\hline \multirow[t]{2}{*}{ Tax share of GDP } & -0.0235 & -0.0191 & -0.0233 & -0.0240 \\
\hline & {$[-1.56]$} & {$[-1.16]$} & {$[-1.54]$} & {$[-1.61]$} \\
\hline \multirow[t]{2}{*}{ Imports from LDCs, no oil } & $0.348^{* * *}$ & $0.334^{* * *}$ & $0.332 * * *$ & $0.345^{* * *}$ \\
\hline & {$[2.84]$} & {$[2.88]$} & {$[2.86]$} & {$[2.90]$} \\
\hline \multirow[t]{2}{*}{ Union density } & $-0.0320^{* * *}$ & $-0.0312^{* * *}$ & $-0.0307^{* * *}$ & $-0.0304^{* * *}$ \\
\hline & {$[-5.14]$} & {$[-5.17]$} & {$[-5.07]$} & {$[-4.87]$} \\
\hline \multirow[t]{2}{*}{ Inflation } & $0.0285^{* * *}$ & $0.0276^{* * *}$ & $0.0279 * * *$ & $0.0278^{* * *}$ \\
\hline & {$[4.79]$} & {$[4.62]$} & {$[4.68]$} & [4.68] \\
\hline \multirow[t]{2}{*}{ Dependency ratio } & 0.00838 & & & \\
\hline & {$[0.59]$} & & & \\
\hline Population growth & & 0.0962 & & \\
\hline \multirow{2}{*}{ Immigration } & & & 0.0668 & \\
\hline & & & {$[0.36]$} & \\
\hline \multirow[t]{2}{*}{ Solow Residual } & & & & 0.363 \\
\hline & & & & {$[0.33]$} \\
\hline \multirow[t]{2}{*}{ Constant } & $44.11^{* *}$ & $44.90^{* * *}$ & $48.46^{* * *}$ & $45.47^{* *}$ \\
\hline & {$[2.35]$} & {$[2.60]$} & {$[2.97]$} & {$[2.33]$} \\
\hline Observations & 744 & 744 & 744 & 744 \\
\hline Countries & 30 & 30 & 30 & 30 \\
\hline Period Effects & Yes & Yes & Yes & Yes \\
\hline $\operatorname{Sargan} \chi^{2}$ & 732.7 & 724.4 & 724.1 & 726.4 \\
\hline p-value Sargan & 0.0829 & 0.1209 & 0.1225 & 0.1109 \\
\hline p-value AR (1) & 0.0004 & 0.0004 & 0.0004 & 0.0004 \\
\hline p-value AR (2) & 0.0450 & 0.0451 & 0.0459 & 0.0458 \\
\hline
\end{tabular}

$\left(^{*}\right),\left[{ }^{* *}\right],\left\{{ }^{* * *}\right\}$ indicate significance at the $(10 \%),[5 \%],\{1 \%\}$ level respectively. Estimation by System-GMM. Dependent variable is the Gini index from Estimated Household Income Inequality (EHII). z-values in brackets. AR (1) and AR (2) refer to the p-value test statistic for first- and second-order autocorrelation on the disturbances of the first-differences equations. p-value Sargan is the p-value of the test statistic for the validity of the overidentifying restriction. Decade dummies included in all models. 
Table 4: Models with interaction of TFP and education

\begin{tabular}{lcc}
\hline & $(1)$ & $(2)$ \\
\hline EHII lagged & $0.561^{* * *}$ & $0.560^{* * *}$ \\
GDP per capita & $(20.81)$ & $(20.82)$ \\
& -5.433 & 1.425 \\
GDP per capita ${ }^{2}$ & $(-1.63)$ & $(0.31)$ \\
& 0.231 & -0.129 \\
GDP growth & $(1.28)$ & $(-0.53)$ \\
& -0.00975 & -0.00776 \\
Union density & $(-0.60)$ & $(-0.48)$ \\
& $-0.0304^{* * *}$ & $-0.0316^{* * *}$ \\
Inflation & $(-4.87)$ & $(-5.03)$ \\
& $0.0278^{* * *}$ & $0.0271^{* * *}$ \\
Tax share of GDP & $(4.68)$ & $(4.57)$ \\
& -0.0240 & -0.0161 \\
Imports from LDCs, no oil & $(-1.61)$ & $(-1.05)$ \\
& $0.345^{* * *}$ & $0.340^{* * *}$ \\
Education & $(2.90)$ & $(2.85)$ \\
& -0.485 & $-49.22^{* *}$ \\
Solow Residual & $(-0.91)$ & $(-2.25)$ \\
& 0.363 & $-8.554^{* *}$ \\
Solow Residual $\times$ Education & $(0.33)$ & $(-2.06)$ \\
Constant & & $4.114^{* *}$ \\
& & $(2.23)$ \\
Observations & $45.47^{* *}$ & $118.2^{* * *}$ \\
Countries & $(2.33)$ & $(3.10)$ \\
Period Effects & 744 & 744 \\
Sargan $\chi^{2}$ & 30 & 30 \\
p-value Sargan & Yes & Yes \\
p-value AR $(1)$ & 726.4 & 722.1 \\
\hline & 0.1109 & 0.1336 \\
& 0.0004 & 0.0004 \\
& 0.0458 & 0.0466 \\
\hline & & \\
& & \\
& &
\end{tabular}

$\left({ }^{*}\right),[* *],\left\{{ }^{* *}\right\}$ indicate significance at the $(10 \%),[5 \%],\{1 \%\}$ level respectively. Estimation by System-GMM. Dependent variable is the Gini index from Estimated Household Income Inequality (EHII). z-values in brackets. AR (1) and AR (2) refer to the p-value test statistic for first- and second-order autocorrelation on the disturbances of the first-differences equations. p-value Sargan is the p-value of the test statistic for the validity of the overidentifying restriction. Decade dummies included in all models. 
Table 5: Models including political regime change

\begin{tabular}{|c|c|c|}
\hline & (1) & (2) \\
\hline EHII lagged & $\begin{array}{c}0.410^{* * *} \\
(11.04)\end{array}$ & $\begin{array}{c}0.459^{* * *} \\
(12.59)\end{array}$ \\
\hline GDP per capita & $\begin{array}{l}-8.146 \\
(-1.38)\end{array}$ & $\begin{array}{l}-5.235 \\
(-0.84)\end{array}$ \\
\hline GDP per capita ${ }^{2}$ & $\begin{array}{l}0.378 \\
(1.17)\end{array}$ & $\begin{array}{l}0.190 \\
(0.57)\end{array}$ \\
\hline GDP growth & $\begin{array}{c}-0.00217 \\
(-0.13)\end{array}$ & $\begin{array}{c}-0.0159 \\
(-0.92)\end{array}$ \\
\hline Democracy & $\begin{array}{c}-0.167^{* * *} \\
(-3.95)\end{array}$ & \\
\hline Democracy $\times$ Ex-Soviet dummy & & $\begin{array}{c}3.795^{*} \\
(1.95)\end{array}$ \\
\hline Democracy $\times$ Western Europe dummy & & $\begin{array}{c}-0.232^{* * *} \\
(-4.74)\end{array}$ \\
\hline Democracy $\times$ Rest of the World dummy & & $\begin{array}{c}-0.0546 \\
(-0.80)\end{array}$ \\
\hline Tax share of GDP & $\begin{array}{c}0.0560^{*} \\
(1.74)\end{array}$ & $\begin{array}{c}0.0597^{*} \\
(1.84)\end{array}$ \\
\hline Education & $\begin{array}{c}2.414^{* *} \\
(2.52)\end{array}$ & $\begin{array}{c}1.690^{*} \\
(1.73)\end{array}$ \\
\hline Imports from LDCs, no oil & $\begin{array}{c}0.259 \\
(1.38)\end{array}$ & $\begin{array}{c}0.380^{* *} \\
(2.04)\end{array}$ \\
\hline Constant & $\begin{array}{c}59.11^{* *} \\
(2.19)\end{array}$ & $\begin{array}{l}46.84^{*} \\
(1.65)\end{array}$ \\
\hline Observations & 765 & 765 \\
\hline Countries & 29 & 29 \\
\hline Period Effects & Yes & Yes \\
\hline Sargan $\chi^{2}$ & 521.1 & 511.9 \\
\hline p-value Sargan & 0.0317 & 0.3012 \\
\hline p-value AR (1) & 0.0005 & 0.0005 \\
\hline p-value AR (2) & 0.0185 & 0.0191 \\
\hline
\end{tabular}

$\left(^{*}\right),\left[^{* *}\right],\left\{{ }^{* *}\right\}$ indicate significance at the $(10 \%),[5 \%],\{1 \%\}$ level respectively. Estimation by Difference-GMM. Dependent variable is the Gini index from Estimated Household Income Inequality (EHII). z-values in brackets. AR (1) and AR (2) refer to the p-value test statistic for first- and second-order autocorrelation on the disturbances of the first-differences equations. p-value Sargan is the p-value of the test statistic for the validity of the overidentifying restriction. Decade dummies included in all models. 
Table 6: Income inequality determinants: Liberal versus social market economies

\begin{tabular}{lccc}
\hline & $(1)$ & $(2)$ & $(3)$ \\
Sample & Total & SME & LME \\
\hline EHII lagged & $0.599^{* * *}$ & $0.714^{* * *}$ & $0.648^{* * *}$ \\
& {$[21.67]$} & {$[21.22]$} & {$[20.41]$} \\
GDP per capita & -2.180 & -13.16 & 0.974 \\
& {$[-0.62]$} & {$[-1.25]$} & {$[0.25]$} \\
GDP per capita ${ }^{2}$ & 0.0558 & 0.626 & -0.100 \\
& {$[0.31]$} & {$[1.17]$} & {$[-0.49]$} \\
GDP growth & -0.00974 & 0.00961 & -0.00494 \\
& {$[-0.65]$} & {$[0.37]$} & {$[-0.29]$} \\
Tax share of GDP & $-0.0607^{* * *}$ & 0.00293 & -0.0325 \\
& {$[-4.01]$} & {$[0.11]$} & {$[-1.27]$} \\
Education & $-1.105^{* *}$ & 0.0113 & $-1.272^{* * *}$ \\
& {$[-2.52]$} & {$[0.02]$} & {$[-2.75]$} \\
Non-oil LDC imports & $0.457^{* * *}$ & 0.150 & $0.302^{* *}$ \\
& {$[3.90]$} & {$[1.16]$} & {$[2.00]$} \\
Constant & $33.19^{* *}$ & 78.44 & 17.51 \\
& {$[1.99]$} & {$[1.52]$} & {$[0.94]$} \\
\hline Observations & 849 & 326 & 523 \\
Countries & 32 & 14 & 18 \\
Period Effects & Yes & Yes & Yes \\
Sargan $\chi^{2}$ & 591.0 & 416.5 & 485.6 \\
p-value Sargan & 0.0893 & 0.5256 & 0.8272 \\
p-value AR (1) & 0.0003 & 0.0037 & 0.0085 \\
p-value AR $(2)$ & 0.0149 & 0.0233 & 0.3056 \\
\hline
\end{tabular}

SME are the Social Market Economies - defined as those countries with a mean tax share above 35\% of the country's GDP. LME are the Liberal Market Economies and are all remaining economies. $\left.\left(^{*}\right),{ }^{* *}\right],\left\{{ }^{* *}\right\}$ indicate significance at the $(10 \%),[5 \%],\{1 \%\}$ level respectively. Estimation by System-GMM. Dependent variable is the Gini index from Estimated Household Income Inequality (EHII). z-values in brackets. AR (1) and AR (2) refer to the p-value test statistic for first- and second-order autocorrelation on the disturbances of the first-differences equations. p-value Sargan is the p-value of the test statistic for the validity of the overidentifying restriction. Decade dummies included in all models. 
Table 7: Determinants of income inequality: Time-varying parameters for trade and union density

\begin{tabular}{|c|c|c|c|}
\hline & $(1)$ & & $(2)$ \\
\hline EHII lagged & $\begin{array}{l}0.541^{* * *} \\
{[19.96]}\end{array}$ & EHII lagged & $\begin{array}{l}0.534^{* * *} \\
{[19.90]}\end{array}$ \\
\hline GDP per Capita & $\begin{array}{l}-1.258 \\
{[-0.35]}\end{array}$ & GDP per Capita & $\begin{array}{l}-2.927 \\
{[-0.88]}\end{array}$ \\
\hline GDP per capita ${ }^{2}$ & $\begin{array}{c}0.0249 \\
{[0.13]}\end{array}$ & GDP per capita ${ }^{2}$ & $\begin{array}{c}0.0972 \\
{[0.55]}\end{array}$ \\
\hline GDP growth & $\begin{array}{c}0.000661 \\
{[0.04]}\end{array}$ & GDP growth & $\begin{array}{c}0.00375 \\
{[0.23]}\end{array}$ \\
\hline Tax Share of GDP & $\begin{array}{c}-0.0374^{* *} \\
{[-2.49]}\end{array}$ & Tax Share of GDP & $\begin{array}{c}-0.0188 \\
{[-1.26]}\end{array}$ \\
\hline Education & $\begin{array}{l}-0.724 \\
{[-1.36]}\end{array}$ & Education & $\begin{array}{l}-0.789 \\
{[-1.49]}\end{array}$ \\
\hline Non-oil LDC Imports & $\begin{array}{l}0.232^{*} \\
{[1.80]}\end{array}$ & Union Density & $\begin{array}{c}-0.0303^{* * *} \\
{[-5.08]}\end{array}$ \\
\hline $\begin{array}{l}\text { Union Density } \\
\text { interacted with time dummy: }\end{array}$ & & $\begin{array}{l}\text { Non-oil LDC Imports } \\
\text { interacted with time dummy: }\end{array}$ & \\
\hline $1963-1966$ & $\begin{array}{c}-0.0590^{* * *} \\
{[-6.50]}\end{array}$ & $1963-1966$ & $\begin{array}{c}-1.314^{* * *} \\
{[-3.34]}\end{array}$ \\
\hline $1967-1971$ & $\begin{array}{c}-0.0497^{* * *} \\
{[-5.65]}\end{array}$ & $1967-1971$ & $\begin{array}{c}-0.909^{* *} \\
{[-2.42]}\end{array}$ \\
\hline $1971-1974$ & $\begin{array}{c}-0.0429^{* * *} \\
{[-5.87]}\end{array}$ & $1971-1974$ & $\begin{array}{c}-0.605^{* *} \\
{[-2.30]}\end{array}$ \\
\hline $1975-1978$ & $\begin{array}{c}-0.0388^{* * *} \\
{[-5.60]}\end{array}$ & $1975-1978$ & $\begin{array}{c}-0.385^{*} \\
{[-1.75]}\end{array}$ \\
\hline $1979-1982$ & $\begin{array}{c}-0.0328^{* * *} \\
{[-4.97]}\end{array}$ & $1979-1982$ & $\begin{array}{l}-0.142 \\
{[-0.73]}\end{array}$ \\
\hline $1983-1986$ & $\begin{array}{l}-0.0309^{* * *} \\
{[-4.67]}\end{array}$ & $1983-1986$ & $\begin{array}{l}-0.366 \\
{[-1.60]}\end{array}$ \\
\hline $1987-1990$ & $\begin{array}{c}-0.0261^{* * *} \\
{[-3.87]}\end{array}$ & $1987-1990$ & $\begin{array}{l}0.0403 \\
{[0.23]}\end{array}$ \\
\hline $1991-1994$ & $\begin{array}{c}-0.0228^{* * *} \\
{[-3.48]}\end{array}$ & $1991-1994$ & $\begin{array}{c}0.373^{* *} \\
{[2.40]}\end{array}$ \\
\hline $1995-1998$ & $\begin{array}{l}-0.0207^{* * *} \\
{[-2.79]}\end{array}$ & $1995-1998$ & $\begin{array}{c}0.391^{* * *} \\
{[3.03]}\end{array}$ \\
\hline $1999-2002$ & $\begin{array}{c}-0.0130 \\
{[-1.35]}\end{array}$ & $1999-2002$ & $\begin{array}{c}0.467^{* * *} \\
{[3.51]}\end{array}$ \\
\hline & $\begin{array}{l}30.36^{*} \\
{[1.76]}\end{array}$ & Constant & $\begin{array}{l}39.59^{* *} \\
{[2.46]}\end{array}$ \\
\hline Observations & 744 & Observations & 744 \\
\hline Countries & 30 & Countries & 30 \\
\hline Period Effects & Yes & Period Effects & Yes \\
\hline Sargan $\chi^{2}$ & 724.1 & Sargan $\chi^{2}$ & 718.5 \\
\hline p-value Sargan & 0.1069 & p-value Sargan & 0.1305 \\
\hline p-value AR (1) & 0.0005 & p-value AR (1) & 0.0004 \\
\hline p-value AR (2) & 0.0612 & p-value AR (2) & 0.0806 \\
\hline
\end{tabular}

$\left(^{*}\right),\left[{ }^{* *}\right],\left\{{ }^{* * *}\right\}$ indicate significance at the $(10 \%),[5 \%],\{1 \%\}$ level respectively. Estimation by System-GMM. Dependent variable is the Gini index from Estimated Household Income Inequality (EHII). z-values in brackets. AR (1) and AR (2) refer to the p-value test statistic for first- and second-order autocorrelation on the disturbances of the first-differences equations. p-value Sargan is the p-value of the test statistic for the validity of the overidentifying restriction. Decade dummies included in all models. 


\section{Appendix}

\section{Data Interpolation in the EHII Dataset}

The lack of consistent panel datasets for countrywide income inequality measures has led several researchers to provide reconstructed inequality data based on regression analysis. The EHII dataset (Galbraith and Kum, 2005) is one of the most widely used examples of such databases. Galbraith and Kum (2005) utilize the information contained in the UTIP-UNIDO measure of dispersion of manufacturing pay in the framework of regression analysis in order to obtain estimates of gross household income inequality (as measured by the Gini index).

Galbraith and Kum (2005) start by estimating a regression model linking the measure of inequality in Deininger and Squire (1996) $\left(D S_{i t}\right)$ to the manufacturing pay dispersion variable $\left(M D_{i t}\right)$, a set of dummy variables which account for the characteristics of the observation in the Deininger and Squire (1996) dataset $\left(D_{j, i t}\right)$ and other socioeconomic variables $\left(X_{k, i t}\right)$. The model used is thus given by

$$
\log D S_{i t}=\alpha+\delta M D_{i t}+\sum_{j} \rho_{j} D_{j, i t}+\sum_{k} \theta_{k} X_{k, i t}+\varepsilon_{i t}
$$

where $\varepsilon_{i t}$ is the regression error, assumed to fulfil the necessary conditions for the standard linear regression model.

Galbraith and Kum (2005) obtain parameter estimates for this regression model using a set of dummy variables that identify the data source as $D_{j, i t}$ variables (whether the inequality measure is based on income or expenditure, whether it is measured at the individual or household level and whether it is a based on a gross or net variable) and the share of employment in the manufacturing sector to total population. With the aid of these parameter estimates, the missing data in $D S_{i t}$ are interpolated as the corresponding conditional expectation, utilizing the available information for the independent variables of the model. A similar regressionbased approach to the imputation of missing data for income inequality can be found in Sala-i Martin (2006). Among other, the recent contribution by Pinkovskiy (2013), which attempts at measuring the change of world inequality and welfare over time, reports that the results of the analysis are similar when using survey data from the World Income Inequality Database (WIID) or the Gini index provided by the EHII dataset. 


\section{Data Sources}

- The Deninger-Squire income inequality dataset is available athttp://go.worldbank. org/UVP09KSJJO.

- The University of Texas Inequality Project publishes the data on income inequality at http://utip.gov.utexas . edu/data.html.

- The Correlates of War data is available at: http://correlatesofwar.org.

- The FDI dataset is available (for observations starting in 1980) at: http://unctadstat. unctad . org/TableViewer/tableView . aspx?ReportId=89.

- The Database on Institutional Characteristics of Trade Unions, Wage Setting, State Intervention and Social Pacts, maintained by Jelle Visser at the Amsterdam Institute for Advanced Labour Studies (AIAS) is freely available at: http://www.uva-aias.net/208. This information was complemented for our analysis with data from OECD Employment Database. The data is available online: http://www.oecd.org/document/34/0,3343, en264933927409171541111,00.html.

- The Polity IV dataset is available and documented online at: http://www. systemicpeace . org/polity/polity4.htm.

- Data on the tax share of GDP are available at the OECD Tax Database at http://www. oecd.org/document/60/0, 3746, en26493453319424601111, 00 .html.

- The data on the share of public expenditures on GDP is taken from the Statistics of Public Expenditure for Economic Development (SPEED) database, compiled by the International Food Policy Research Institute (IFPRI) online at http://www.ifpri.org/ book-39/ourwork/programs/priorities-public-investment/speed-database.

- Unemployment data from Armingeon et al. (2010) and Armingeon and Romana (2007) are available online at http://www.ipw.unibe.ch/content/team/klausarmingeon, while female labour participation data are sourced from the OECD's Labour Force Statistics (MEI), available online at: http://stats.oecd.org/.

- The Barro-Lee education data are available online at: www.barrolee.com.

- Total factor productivity data from the conference board available at https://www. conference-board.org/data/economydatabase/ were used for the robustness analysis. 


\section{Inequality Measures and Tax Shares: Descriptive Statistics}

Table A1: Descriptive statistics, Gini index (EHII) for our sample of 32 developed countries

\begin{tabular}{lccccc}
\hline Country & Observations & Mean & Std.Dev. & Min & Max \\
\hline Australia & 39 & 33.78 & 0.255 & 30.66 & 38.83 \\
Austria & 37 & 35.03 & 0.114 & 33.31 & 40.42 \\
Belgium & 35 & 36.06 & 0.133 & 34.06 & 38.18 \\
Canada & 39 & 36.07 & 0.123 & 34.26 & 38.19 \\
Chile & 38 & 44.29 & 0.259 & 38.89 & 48.58 \\
Czech Republic & 33 & 23.84 & 0.320 & 19.81 & 33.16 \\
Denmark & 36 & 30.95 & 0.483 & 29.76 & 31.98 \\
Finland & 38 & 31.72 & 0.159 & 27.95 & 33.66 \\
France & 21 & 35.01 & 0.819 & 33.92 & 36.42 \\
Germany & 38 & 32.77 & 0.126 & 29.65 & 36.48 \\
Greece & 36 & 40.41 & 0.204 & 33.64 & 42.87 \\
Hungary & 38 & 31.09 & 0.482 & 23.84 & 40.02 \\
Iceland & 29 & 36.14 & 0.277 & 31.34 & 40.95 \\
Ireland & 38 & 38.26 & 0.278 & 33.59 & 46.23 \\
Israel & 39 & 39.87 & 0.284 & 35.31 & 43.34 \\
Italy & 34 & 35.73 & 0.244 & 31.73 & 40.09 \\
Japan & 39 & 37.44 & 0.229 & 35.07 & 43.12 \\
Luxembourg & 38 & 32.78 & 0.158 & 29.77 & 35.17 \\
Mexico & 31 & 41.08 & 0.185 & 35.86 & 44.03 \\
Netherlands & 38 & 32.82 & 0.153 & 29.65 & 35.10 \\
New Zealand & 36 & 35.21 & 0.262 & 32.19 & 42.14 \\
Norway & 39 & 32.30 & 0.145 & 29.29 & 35.72 \\
Poland & 31 & 30.50 & 0.404 & 25.78 & 38.51 \\
Portugal & 32 & 39.93 & 0.200 & 35.13 & 43.54 \\
Slovak Republic & 7 & 33.93 & 0.298 & 30.19 & 36.70 \\
Slovenia & 16 & 31.30 & 0.346 & 24.95 & 35.32 \\
South Korea & 39 & 39.21 & 0.222 & 36.07 & 43.36 \\
Spain & 40 & 38.48 & 0.295 & 30.97 & 41.45 \\
Sweden & 38 & 27.98 & 0.111 & 25.89 & 30.21 \\
Turkey & 38 & 43.23 & 0.237 & 40.19 & 47.97 \\
United Kingdom & 34 & 30.35 & 0.363 & 26.45 & 36.77 \\
United States & 38 & 37.01 & 0.116 & 34.79 & 38.40 \\
\hline & & & & & \\
& & & & & \\
& 39 & & & &
\end{tabular}


Table A2: Descriptive statistics, level and change in Gini index (EHII) since the eighties

\begin{tabular}{lcccc}
\hline & $\begin{array}{c}\text { Mean between } \\
1980 \text { and } 1986\end{array}$ & $\begin{array}{c}\text { Last observation } \\
\text { of EHII data }\end{array}$ & $\begin{array}{c}\text { Change in percent since } \\
1980-1986\end{array}$ & $\begin{array}{c}\text { Last year of } \\
\text { EHII observation }\end{array}$ \\
\hline Iceland & 39,62 & 34,27 & $-13,51$ & 1996 \\
Belgium & 36,89 & 36,70 & $-0,53$ & 1997 \\
Chile & 45,88 & 46,51 & 1,36 & 2000 \\
Denmark & 31,04 & 31,51 & 1,50 & 1998 \\
United States & 37,58 & 38,31 & 1,92 & 2001 \\
Israel & 41,39 & 42,90 & 3,64 & 2001 \\
Portugal & 38,37 & 39,95 & 4,09 & 2000 \\
Spain & 35,05 & 36,62 & 4,48 & 2002 \\
Greece & 39,72 & 41,56 & 4,62 & 1998 \\
Canada & 36,23 & 38,00 & 4,89 & 2001 \\
Luxembourg & 32,59 & 34,40 & 5,54 & 2000 \\
France & 34,39 & 36,42 & 5,88 & 2000 \\
Norway & 31,65 & 34,16 & 7,92 & 2001 \\
Sweden & 26,62 & 28,96 & 8,78 & 2000 \\
Finland & 30,24 & 32,92 & 8,84 & 2000 \\
Italy & 33,33 & 36,31 & 8,93 & 2000 \\
Mexico & 39,95 & 43,83 & 9,70 & 2000 \\
Netherlands & 31,68 & 35,10 & 10,78 & 2000 \\
Germany & 32,80 & 36,48 & 11,20 & 2000 \\
Turkey & 42,10 & 47,97 & 13,93 & 2000 \\
Australia & 32,97 & 38,35 & 16,29 & 2001 \\
Austria & 34,74 & 40,42 & 16,34 & 2000 \\
New Zealand & 33,34 & 38,94 & 16,79 & 1998 \\
Japan & 36,50 & 43,12 & 18,12 & 2001 \\
Ireland & 37,23 & 44,80 & 20,33 & 2000 \\
United Kingdom & 29,28 & 36,77 & 25,58 & 2000 \\
Slovenia & $24,95 *$ & 34,42 & 43,96 & 2002 \\
Poland & 26,91 & 38,51 & 43,45 & 2000 \\
Hungary & 27,79 & 39,87 & 50,01 & 1995 \\
Czech Republic & 22,10 & 33,16 & & \\
\hline
\end{tabular}

* As Slovenia was not an independent country in the beginning of the 1980s the value of Slovenia is from 1987 - which is the first available from the EHII dataset.

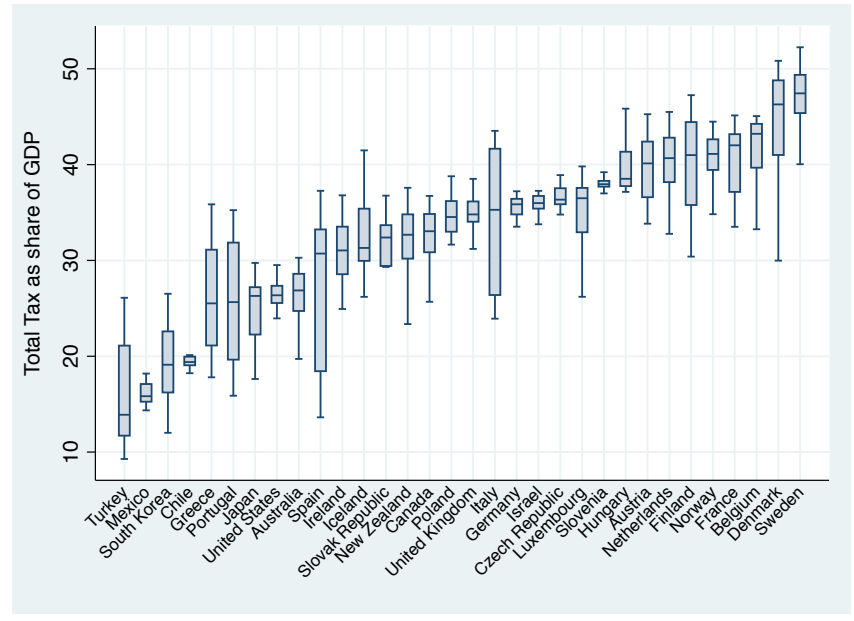

Figure A1: Total taxes as share of GDP 